\title{
The Role of Anemia Management in Improving Outcomes for African- Americans with Chronic Kidney Disease
}

\author{
Janice P. Lea ${ }^{a}$ Keith Norris ${ }^{b}$ Lawrence Agodoac \\ ${ }^{a}$ Department of Medicine, Emory University, Renal Division, Atlanta, Ga., ${ }^{b}$ Clinical Research Center, Charles R. Drew \\ University of Medicine and Science, and David Geffen School of Medicine, University of California Los Angeles \\ (UCLA), Los Angeles, Calif., and ${ }^{C}$ Chronic Kidney Disease and End Stage Renal Disease Programs and Office of \\ Minority Health Research Coordination, National Institute of Diabetes and Digestive and Kidney Diseases, \\ National Institutes of Health, Bethesda, Md., USA
}

\section{Key Words}

Anemia management - Diabetes mellitus - Hypertension • Chronic kidney disease $\cdot$ Dialysis

\begin{abstract}
Chronic kidney disease (CKD) is a serious threat to AfricanAmerican public health. In this population CKD progresses to end-stage renal disease (ESRD) at quadruple the rate in Caucasians. Factors fueling progression to ESRD include diabetes and hypertension, which show high prevalences and accelerated renal damage in African- Americans, as well as possible nutritional, socioeconomic, and genetic factors. Anemia, a common and deleterious complication of CKD, is more prevalent and severe in African-American than Caucasian patients at each stage of the disease. Proactive management of diabetes, hypertension, anemia, and other complications throughout the course of CKD can prevent or delay disease progression and alleviate the burden of ESRD for the African-American community. Currently, African-Americans with CKD are less likely than Caucasian patients to receive anemia treatment before and after the onset of dialysis. Although African-Americans often require higher doses of erythropoiesis-stimulating agents, this may result from late treatment initiation, lower hemoglobin levels, or the pres-
\end{abstract}

\section{KARGER \\ Fax +41 613061234 \\ E-Mail karger@karger.ch}

(c) 2008 S. Karger AG, Basel

www.karger.com ence of comorbidities such as diabetes and inflammation, although racial differences in response cannot be excluded. This review explores racial-specific challenges and potential solutions in renal anemia management to improve outcomes in African-American patients.

Copyright $\odot 2008$ S. Karger AG, Basel

\section{Introduction}

Chronic kidney disease (CKD) is highly prevalent in adults in the United States, with African-Americans and other racial and ethnic minority groups at increased risk of the disease $[1,2]$. Decline of renal function is fueled by diabetes and hypertension, risk factors widespread in the African-American population [3]. Compared with Caucasians, African-Americans show an incrementally larger prevalence across advancing stages of CKD progression [4-6], and a 3- to 4-fold greater incidence of endstage renal disease (ESRD) $[2,4,7]$. Anemia, a common consequence of $\mathrm{CKD}$, is more prevalent and severe in African-American than Caucasian CKD patients $[2,5]$, is intensified by diabetes [8], and is associated with cardiovascular risk [9] and accelerated loss of renal function $[10,11]$. 
Table 1. Stages and prevalences of CKD by ethnic group

\begin{tabular}{lcll}
\hline & eGFR, ml/min/1.73 $\mathrm{m}^{2}$ & $\begin{array}{l}\text { Prevalence among non-Hispanic } \\
\text { African-American NHANES } \\
1999-2004 \text { participants (\%, 95\% CI) }\end{array}$ & $\begin{array}{l}\text { Prevalence among non-Hispanic } \\
\text { Caucasian NHANES 1999-2004 } \\
\text { Participants (\%, 95\% CI) }\end{array}$ \\
\hline Stage 1 & $\geq 90$ with evidence of kidney damage & $9.4(8.0-10.9)$ & $4.2(3.7-4.9)$ \\
Stage 2 & $60-89$ with evidence of kidney damage & $4.8(3.9-5.7)$ & $5.8(5.0-6.6)$ \\
Stage 3 & $30-59$ & $4.7(4.0-5.6)$ & $5.8(5.3-6.4)$ \\
Stages 4 and 5 combined & $<30$ including dialysis & $1.1(0.7-1.6)^{*}$ & $0.3(0.2-0.5)$ \\
\hline
\end{tabular}

eGFR = Estimated glomerular filtration rate; NHANES = National Health and Nutrition Examination Survey.

* NHANES 1999-2004 data [4] calculated combined prevalences for stages 4 and 5. Stages adapted from reference [117].

Disproportionate progression to ESRD among racial and ethnic minorities creates added public health burdens for local communities. The excess prevalence has been estimated to contribute more than $25 \%$ of the total cost in the US ESRD system, which now exceeds USD 32 billion a year [2, 7]. Earlier detection and intervention to treat both the causes of CKD (e.g. diabetes, hypertension) and its consequences (anemia, cardiovascular disease, bone disease) may prevent or delay the progression of CKD [3].

Healthy and iron-replete African-Americans typically have lower average hemoglobin $(\mathrm{Hb})$ levels than Caucasians, reflecting, among other factors, the effects of an alpha-thalassemia deletion allele (gene frequency 0.169) [12]. Iron deficiency anemia is also frequent in AfricanAmericans, with prevalences ranging up to $19 \%$ in premenopausal black women [13]. These baseline factors, combined with the erythropoietic deficits of CKD, result in lower mean $\mathrm{Hb}$ and greater risk of anemia in AfricanAmerican than Caucasian patients throughout the course of CKD $[2,5]$. Consequences of untreated anemia of CKD include fatigue, cognitive impairment, and reduced exercise tolerance [14] as well as increased cardiovascular morbidity [15-17], leading to increased hospitalization $[18,19]$, economic burden [19, 20], and mortality [21-23]. Patients with early CKD and untreated anemia have been shown to progress to ESRD more rapidly than treated anemic patients or non-anemic patients $[10,11]$.

Treatment for anemia of CKD began in the 1960s and 1970s with blood transfusions, but these were associated with iron overload [24], immune sensitization [25], and occasional viral transmission [26]. Androgen treatment of anemia has been associated with adverse hepatic and endocrine events [27]. The development of recombinant erythropoietins in the 1980s revolutionized anemia treatment in CKD [28], and such erythropoiesis-stimulating agents (ESAs) remain the foundation of current anemia management [27]. Recent years have seen an evolution in ESA therapies toward agents with longer half-lives and extended administration intervals $[29,30]$.

Despite recent improvements in anemia management, African-Americans still have suboptimal rates of achieving recommended hemoglobin targets [2]. This article surveys current data on the epidemiology, course, and treatment of CKD and its complications in AfricanAmericans; highlighting racial-specific challenges and potential solutions for improving anemia management in the patient with CKD or ESRD.

\section{CKD Prevalence and Progression to ESRD in African-Americans}

A recent analysis of NHANES 1999-2004 data [4] indicates that the overall prevalence of CKD is only slightly higher among African-Americans (19.9\%) than Caucasians (16.1\%). In this data set, stage 1 CKD (with nearnormal estimated glomerular filtration rate [eGFR] but evidence of proteinuria or kidney damage) was more prevalent among African-Americans than Caucasians. By contrast, rates of stages 2 and 3 were higher among Caucasians (table 1). A similar prevalence pattern was reported for the Kidney Early Evaluation Program participants, with stages 1 and 2 CKD being more common in African-Americans than Caucasians [5]. In contrast to the modest differences in early-CKD prevalences and trends toward lower rates of stages 2 and 3 CKD among African-Americans, ESRD is roughly 4 times as prevalent among African-Americans as among Caucasians [2].

Research into the causes of racial disparities in CKDrelated health outcomes is ongoing. Known risk factors 
for progressive kidney disease include African-American race, level of blood pressure control, proteinuria, low socioeconomic status, and genetic influences $[6,35,36,37$, $41,42]$. The incidence of hypertension among 20 - to $44-$ year-old men is 20 times greater for African-Americans than their Caucasian counterparts [2]. Family history of ESRD predicts increased risk of ESRD [34, 35], and 2 genetic loci (the plasma kallikrein gene and the human homolog of the rodent renal failure 1 gene) have been correlated with ESRD in African-American kindreds [34]. Albuminuria or proteinuria, a common initial presentation of nephropathy, is associated with CKD progression in both diabetic and hypertensive patients [41-43]. The African-American Study of Kidney Disease and Hypertension (AASK) found that increasing rates of proteinuria at a given GFR level predicted worsening clinical outcomes [41]; additionally, GFR decline accelerated at low levels of renal function [53]. Furthermore, poverty and low educational attainment are strong socioeconomic predictors of proteinuria in African-Americans [44].

Because African-Americans have a high prevalence of CKD and a differential risk of progression to ESRD, vigorous screening and treatment for diabetes, hypertension, and early stages of CKD are especially important in the African-American population. Primary care physicians should take action to reduce behavioral risk factors (smoking, substance abuse, poor nutrition, sedentarism), monitor patients longitudinally for albuminuria/proteinuria and abnormal GFR, and refer them to nephrologists as appropriate. Management of conditions predisposing to CKD and ESRD can reduce the public health burden attributable to kidney failure.

\section{Clinical Management of CKD and Anemia}

Prevention and care of hypertension and diabetes in the general African-American population can help reduce the burden of CKD. Patients with established CKD, regardless of stage, require proactive treatment of clinical perturbations as they develop (e.g. hypertension, diabetes, anemia) to retard disease progression and attenuate the ESRD burden for the African-American community. Strategies for clinical management of hypertension, diabetes, and anemia to improve the renal prognosis in this population are discussed below.

\section{Hypertension}

Aggressive treatment of hypertension is essential to reduce the burden of nephropathy in this population. In
African-Americans with hypertension, a systolic blood pressure goal of 135-140 $\mathrm{mm} \mathrm{Hg}$ is reasonable; however, African-Americans with CKD or diabetes require a lower blood pressure goal of $\leq 130 / 80 \mathrm{~mm} \mathrm{Hg}$ [55]. Available data including the Antihypertensive and Lipid-Lowering Treatment to Prevent Heart Attack Trial (ALLHAT) [56] support the use of diuretics as first-line treatment to reduce blood pressure and risk of cardiovascular disease in African-Americans with hypertension; however, as in other patients, combination therapy may be more effective in achieving blood pressure reduction goals [57]. For patients with uncomplicated hypertension $\geq 155 / 100$ $\mathrm{mm} \mathrm{Hg}$, recent guidelines for therapy in African-American patients [40] suggest first-line combinations of a diuretic with a different drug class (beta-blocker, angiotensin-converting enzyme inhibitor, or angiotensin-receptor blocker).

Combination antihypertensive therapy for patients with diabetes or known CKD should include renoprotection with an agent acting on the renin-angiotensin system [3].

In a 36-month interim analysis of the AASK trial, the angiotensin-converting enzyme inhibitor ramipril slowed GFR decline and reduced proteinuria in patients with mild to moderate renal insufficiency (baseline proteinuria $>300 \mathrm{mg} /$ day) $[58,59]$.

\section{Diabetes}

African-Americans are more likely than Caucasians to have diabetes [61]; poorly controlled diabetes increases risk of renal failure and premature cardiovascular disease [62]. With long-standing diabetes (10-15 years), glomerular histologic changes lead to frank diabetic nephropathy [63]. Preventing or halting diabetic nephropathy requires a comprehensive intervention to restore and maintain normoglycemia, reduce blood pressure to $\leq 130 / 80$ $\mathrm{mm} \mathrm{Hg}$, control proteinuria, reduce glycated hemoglobin and dyslipidemia, and address behavioral risk factors [64]. Evidence supports blood pressure control as arguably, the most important intervention to retard progressive renal disease as well as other microvascular complications of diabetes $[125,126]$.

\section{Anemia}

Anemia resulting from renal endocrine dysfunction accompanies CKD regardless of the source of kidney damage, with hemoglobin $(\mathrm{Hb})$ measurably decreasing as GFR falls below $60 \mathrm{ml} / \mathrm{min} / 1.73 \mathrm{~m}^{2}$. In the Prevalence of Anemia in Early Renal Insufficiency (PAERI) survey, the prevalence of anemia $(\mathrm{Hb}<12 \mathrm{~g} / \mathrm{dl})$ increased from $26.7 \%$ 
Table 2. Prevalence of anemia among Kidney Early Evaluation Program participants with CKD [5] by stage and race

\begin{tabular}{|c|c|c|c|c|}
\hline & \multicolumn{2}{|c|}{$\begin{array}{l}\text { Anemia, WHO definition } \\
\text { prevalence, } \%\end{array}$} & \multicolumn{2}{|c|}{$\begin{array}{l}\text { Anemia, KDOQI definition }{ }^{\mathrm{b}} \\
\text { prevalence, } \%\end{array}$} \\
\hline & African-Americans & Caucasians & African-Americans & Caucasians \\
\hline Stage 1 (with albumin/creatinine ratio $\geq 30$ ) & 23.3 & 6.4 & 13.5 & 3.3 \\
\hline Stage 2 (with albumin/creatinine ratio $\geq 30$ ) & 20.9 & 10.1 & 12.7 & 6.5 \\
\hline Stage 3 & 26.4 & 12.7 & 21.3 & 9.5 \\
\hline Stages $4-5$ & 70.5 & 51.2 & 59.1 & 42.1 \\
\hline
\end{tabular}

KDOQI = Kidney Disease Outcomes and Quality Initiative; WHO = World Health Organization.

${ }^{\mathrm{a}} \mathrm{Hb}<13.0 \mathrm{~g} / \mathrm{dl}$ in men and postmenopausal women or $<12.0 \mathrm{~g} / \mathrm{dl}$ in premenopausal women [68].

${ }^{\mathrm{b}} \mathrm{Hb}<11.0 \mathrm{~g} / \mathrm{dl}$ in premenopausal women and prepubertal children and $<12.0 \mathrm{~g} / \mathrm{dl}$ in postmenopausal women and adult men [27].

Adapted from data in reference [5].

in stage $3 \mathrm{CKD}$ to $76 \%$ in stage 5 [65]; anemia is near-universal in incident ESRD patients. Anemia develops earlier and more severely in patients with diabetic nephropathy than in CKD patients without diabetes $[8,66]$.

In the general population as well as in all stages of $\mathrm{CKD}$, anemia has been shown to be more prevalent in African-Americans than Caucasians (table 2) [5], perhaps reflecting low $\mathrm{Hb}$ prior to $\mathrm{CKD}$ onset [12] and/or higher prevalence of iron deficiency [13]. African-American PAERI participants had prevalence odds ratios of 1.61 (95\% CI 1.40-1.85; $\mathrm{p}<0.0001)$ for $\mathrm{Hb}<12 \mathrm{~g} / \mathrm{dl}$ and 2.03 (95\% CI 1.63-2.52; $\mathrm{p}<0.0001$ ) for $\mathrm{Hb}<10 \mathrm{~g} / \mathrm{dl}$ relative to Caucasian patients [65]. Current guidelines for diagnosing anemia [27] do not take into account gender or racial differences in baseline $\mathrm{Hb}$.

When anemia decreases tissue oxygenation, the cardiovascular system compensates with tachycardia, vasodilation, and increased cardiac work, leading over time to left ventricular hypertrophy [67]. Roughly $39 \%$ of stage 3-4 CKD patients have left ventricular hypertrophy [68]; its prevalence rises to almost $75 \%$ at dialysis initiation [69], suggesting that cardiac remodeling begins early in the course of CKD [9]. Hypertension also contributes to left ventricular hypertrophy in African-Americans [70]. Among African-American Atherosclerosis Risk in Communities participants aged $50-75$ years, lower $\mathrm{Hb}$ predicted larger left ventricular diameter even after adjusting for kidney function [9].

Treating anemia of CKD with ESAs augments diminished renal erythropoietin production and alleviates tissue hypoxia, which in turn may prevent or reverse left ventricular hypertrophy [21, 71]. Anemia treatment at CKD stages prior to dialysis is associated with improved quality of life [72] and physical activity [14]. With safe $\mathrm{Hb}$ targets generally in the range of 11-12 g/dl [73], ESA treatment may attenuate cardiovascular [21,71] and renal complications [74-76]. Untreated anemia is associated with accelerated progression to ESRD [10, 11]. Conversely, observational studies indicate that receipt of anemia treatment before reaching ESRD is strongly associated with delayed ESRD onset [11] and reduced mortality on dialysis [20, 22, 77]. Recent clinical trials [78, 79] have raised cautions $[73,80]$ regarding the optimal $\mathrm{Hb}$ target range and patient selection for erythropoietic treatment. The exact mechanism underlying the increased morbidity and mortality with higher than currently recommended hemoglobin levels remain unclear. According to the 2007 Kidney Disease Outcome Quality Initiative (KDOQI) guideline update [73], $\mathrm{Hb}$ targets $\geq 13.0 \mathrm{~g} / \mathrm{dl}$ are associated with increased cardiovascular risk; however, among patients treated to appropriate $\mathrm{Hb}$ targets (11-12 g/dl), attainment of higher Hb levels within the target range is associated with decreased mortality and hospitalization.

ESAs currently approved in the US include epoetin alfa (half-life $4-11$ h i.v., 19-25 h s.c. [81]; administered 1-3 times weekly [TIW-Q1W]) and darbepoetin alfa (Aranesp $^{\mathrm{TM}}$; half-life $18-25$ h i.v., 49 h s.c. [81]; administered every 1-2 weeks [Q1W-Q2W]). For extended dosing options, the novel agent methoxy polyethylene glycol epoetin beta (CERA), a continuous ery thropoietin receptor activator, has a prolonged half-life unaffected by administration route (134 h i.v.; 137 h s.c. [82]), permitting dosing intervals as infrequent as once monthly [83]. Phase II and III studies show that CERA effectively corrects and maintains $\mathrm{Hb}$ in ESRD patients requiring dialysis [83, 84] and CKD patients not requiring dialysis [85]. CERA was recently approved by the US Food and Drug Administra- 
tion but it is not currently available for use in the US due to a recent patent legal ruling.

An important challenge in managing the anemia of CKD is to maintain adequate iron utilization and stores. ESAs are not maximally effective in the setting of iron deficiency. Decreased iron stores (absolute iron deficiency) or decreased availability of iron (functional iron deficiency) are the most common reasons for ESA resistance in patients with CKD/ESRD. It is recommended in CKD patients that iron saturation should be $>20 \%$ and serum ferritin be $>100-200$ (in CKD and ESRD, respectively) before ESAs are started. It has been well-described that African-Americans have lower serum hemoglobins compared to Caucasians [130]; however, one report does not indicate that this difference is due to iron deficiency [128]. Others have reported that serum ferritins are higher in African-Americans citing genetic/familial segregations [129].

Additional anemia therapies are also on the horizon. Hematide is a synthetic, nonrecombinant peptide with a novel amino acid sequence unrelated to erythropoietin; it activates the erythropoietin receptor to induce proliferation and differentiation of erythroid progenitor cells into mature erythrocytes [86, 87]. Emerging small-molecule agents FG-2216 and FG-4592 [88] act upstream of erythropoietin and its receptor by stabilizing hypoxia-inducible factor (HIF-1 alpha), a nuclear transcription factor that activates erythropoietin gene production [89] and regulates iron absorption, metabolic response, and vasculogenesis. Thus, these agents are reported to increase erythropoiesis and improve iron balance in patients with anemia and systemic inflammation. HIF-1 alpha stabilizers are the first oral erythropoietic therapies developed for renal anemia, and are currently in phase 2 of clinical development [88].

\section{Anemia Management in African-Americans through the Course of CKD}

African-Americans at all stages of CKD benefit from early and ongoing anemia management. Although these patients often receive higher ESA doses [90-92], it is difficult to distinguish the effects of nutritional deficiency, lower pretreatment $\mathrm{Hb}$ levels, and delayed ESA initiation from possible racial-specific biological effects on ESA responsiveness $[1,93]$. In the Procrit ${ }^{\circledR}$ Dosed Once Weekly in the Patients with Anemia due to Early Renal Insufficiency (POWER) study [94], a post-hoc analysis reported that African-American nonsmokers demonstrated a sta- tistically significant decreased response to epoetin alfa compared with nonsmokers of other races (mean $\mathrm{Hb}$ at week 16: 11.61 vs. $11.86 \mathrm{~g} / \mathrm{dl}, \mathrm{p}=0.02$ ); however, whether this was a clinically significant difference in response is not known. In this same trial, African-American smokers responded comparably to other participants according to statistical analyses.

\section{Anemia Treatment at Stages prior to ESRD}

Only about a third of incident dialysis patients receive treatment for anemia before the transition to dialysis [68]. The rate of pre-ESRD anemia treatment varies geographically [95] and ethnically [96]. Among 56,593 incident dialysis patients in Georgia and the Carolinas, fewer African-Americans than Caucasians had received ESAs before dialysis onset (22.5 vs. $27.2 \%$; OR $0.78,95 \%$ CI $0.75-0.81$ ) despite significantly lower mean $\mathrm{Hb}$ at presentation [96]. A recent report of 620,674 patients initiating dialysis between 1995 and 2003 showed that non-Hispanic Blacks had lower hematocrit levels and less likely to receive ESA therapy than non-Hispanic Whites [131]. The effects of anemia or ESA use on the progression of CKD have been studied predominantly in Caucasian patients [68], and more specific research is needed to explore the consequences of anemia and the outcomes of its treatment in African-Americans with CKD [1].

ESA treatment is typically initiated when $\mathrm{Hb}$ concentration falls to $\leq 11.0 \mathrm{~g} / \mathrm{dl}$ [14]. Iron status should be assessed before ESA initiation and monitored during therapy [97]. Iron supplementation is required to maximize erythropoietic yield. A course of oral iron supplementation (e.g. ferrous sulfate) is reasonable in CKD patients with serum ferritin $<100 \mathrm{ng} / \mathrm{ml}$ or transferrin saturation $<20 \%$; if this is ineffective or poorly tolerated, intravenous iron may be appropriate [14]. Novel iron agents are under investigation; of special note for CKD outpatients, heme iron polypeptide has been reported to enhance oral absorption through the gut heme iron receptor [98].

In outpatients with CKD, extended ESA administration intervals are desirable for convenience and enhanced adherence [27]. Although the approved intervals of existing agents are frequent (Q1W-TIW for epoetin alfa and Q1W-Q2W for darbepoetin alfa), investigations are underway to assess the potential of using current ESAs at extended dosing intervals (table 3). In the Procrit ${ }^{\circledR}$ for Maintenance Phase Treatment of Patients with Anemia due to Chronic Kidney Disease (PROMPT) study [99], the proportion of patients maintaining mean $\mathrm{Hb} \geq 11 \mathrm{~g} /$ $\mathrm{dl}$ declined as the epoetin dosing interval increased. A retrospective chart review of extended epoetin intervals 
Table 3. Studies of extended dosing intervals with current ESAs

\begin{tabular}{|c|c|c|c|c|}
\hline Drug & $\begin{array}{l}\text { Study and } \\
\text { reference }\end{array}$ & Patients & Regimen & Key results \\
\hline \multicolumn{5}{|c|}{ Patients with CKD not on dialysis } \\
\hline Epoetin- $\alpha$ & $\begin{array}{l}\text { PROMPT } \\
\text { (randomized } \\
\text { maintenance } \\
\text { study) [99] }\end{array}$ & $\begin{array}{l}\text { previously treated with } \\
\text { epoetin } \geq 2 \text { months } \\
(\mathrm{n}=519 ; \text { modified ITT } \\
\text { population } \mathrm{n}=445 ; \text { mean } \\
\text { pre-study dose } 11,478 \mathrm{U})\end{array}$ & $\begin{array}{l}\text { 10,000 U/week Q1W ( } n=130 ; 26.1 \% \text { Afr. Am.) } \\
\text { 20,000 U/week Q2W ( } n=131 ; 22.1 \% \text { Afr. Am.) } \\
30,000 \text { U/week Q3W }(n=132 ; 25.8 \% \text { Afr. Am.) } \\
\text { 40,000 U/week Q4W ( } n=126 ; 24.9 \% \text { Afr. Am.) } \\
16 \text { wk treatment }\end{array}$ & $\begin{array}{l}\text { mean final } \mathrm{Hb} \text { of Q2, Q4W groups } \\
\text { statistically non-inferior to Q1W group; } \\
\mathrm{Hb} \geq 11.0 \mathrm{~g} / \mathrm{dl} \text { maintained in } 93.5 \% \text { of } \\
\mathrm{Q} 1 \mathrm{~W}, 89.5 \% \text { of } \mathrm{Q} 2 \mathrm{~W}, 77.2 \% \text { of } \mathrm{Q} 3 \mathrm{~W}, \\
\text { and } 76.0 \% \text { of Q4W patients }\end{array}$ \\
\hline Epoetin- $\alpha$ & $\begin{array}{l}\text { retrospective } \\
\text { chart review } \\
{[100]}\end{array}$ & $\begin{array}{l}\text { treated with epoetin Q2W } \\
\text { to }>\text { Q4W for } \geq 3 \text { months in } \\
\text { private US nephrology } \\
\text { practices }(n=243 ; 11.6 \% \\
\text { Afr. Am.) }\end{array}$ & $\begin{array}{l}\text { Q1W }(n=37), \text { mean dose } 11,080 \pm 3,730 \mathrm{U} \\
\text { Q2W }(\mathrm{n}=124), 15,984 \pm 8,788 \mathrm{U} \\
\text { Q3W }(\mathrm{n}=22), 21,000 \pm 10,415 \mathrm{U} \\
\text { Q4W }(\mathrm{n}=30), 16,700 \pm 6,839 \mathrm{U} \\
>\text { Q4W }(\mathrm{n}=9), 17,333 \pm 8,832 \mathrm{U}\end{array}$ & $\begin{array}{l}\mathrm{Hb} \geq 11.0 \mathrm{~g} / \mathrm{dl} \text { maintained in } 73.0 \% \text { of } \\
\mathrm{Q} 1 \mathrm{~W}, 78.9 \% \text { of } \mathrm{Q} 2 \mathrm{~W}, 95.5 \% \text { of } \mathrm{Q} 3 \mathrm{~W}, \\
90.0 \% \text { of } \mathrm{Q} 4 \mathrm{~W} \text {, and } 100.0 \% \text { of }>\mathrm{Q} 4 \mathrm{~W} \\
\text { patients }\end{array}$ \\
\hline Darbepoetin- $\alpha$ & $\begin{array}{l}\text { multicenter } \\
\text { open-label } \\
\text { study [101] }\end{array}$ & $\begin{array}{l}\text { treated with stable dose of } \\
\text { s.c. darbepoetin Q2W for } \\
\geq 6 \text { weeks before enrollment } \\
(\mathrm{n}=98,35 \% \text { Afr. Am.; } \\
\text { modified ITT population } \\
\mathrm{n}=97)\end{array}$ & $\begin{array}{l}\text { converted from prior Q2W to once monthly for } \\
29 \text { weeks (mean baseline dose } 88.7 \pm 49.9 \mu \mathrm{g} \\
\text { mean evaluation period dose } 86.6 \pm 78.8 \mu \mathrm{g} \text { ) }\end{array}$ & $\begin{array}{l}\mathrm{Hb} 10-12 \mathrm{~g} / \mathrm{dl} \text { maintained in } 77 \% \\
\text { overall (95\% CI } 71-87 \%) \text { and } 85 \%(95 \% \\
\text { CI } 78-93 \%) \text { of those completing } \\
\text { evaluation period }\end{array}$ \\
\hline Darbepoetin- $\alpha$ & $\begin{array}{l}\text { simplify the } \\
\text { treatment } \\
\text { of anemia } \\
\text { with Aranesp } \\
\text { (STAAR) [102] }\end{array}$ & $\begin{array}{l}\text { previously treated with } \\
\text { Q1W epoetin }(\mathrm{n}=524 \\
21.2 \% \text { Afr. Am.) }\end{array}$ & $\begin{array}{l}\text { s.c. Q2W darbepoetin ( } 20 \text { weeks' titration, } 12 \\
\text { week evaluation; up to } 20 \text { weeks extension } \\
\text { period; mean baseline dose } 49.7 \pm 21.9 \mu \mathrm{g} \text {; } \\
\text { mean evaluation period dose } 48.9 \pm 35.5 \mu \mathrm{g} \text { ) }\end{array}$ & $\begin{array}{l}\text { baseline mean } \mathrm{Hb} 11.2 \pm 1.27 \mathrm{~g} / \mathrm{dl} \text {; } \\
\text { evaluation period least-squares mean } \\
\mathrm{Hb} 11.4 \pm 0.04 \mathrm{~g} / \mathrm{dl}\end{array}$ \\
\hline \multicolumn{5}{|c|}{ Patients with anemia of CKD on dialysis } \\
\hline Epoetin & $\begin{array}{l}\text { meta-analysis } \\
{[118]}\end{array}$ & $\begin{array}{l}11 \text { studies totaling } \\
719 \text { patients }\end{array}$ & TIW, BIW, Q1W & $\begin{array}{l}\text { no significant difference in maintaining } \\
\text { target Hb between BIW and Q1W (one } \\
\text { study, } 20 \text { patients: RR } 1.00,95 \% \text { CI } \\
0.42-2.40 \text { ) } \\
\text { no significant difference in maintaining } \\
\text { target Hb between TIW and Q1W } \\
\text { (three studies: weighted mean } \\
\text { difference }-0.31,95 \% \text { CI }-0.67 \text { to } 0.06 \text { ) }\end{array}$ \\
\hline Darbepoetin & $\begin{array}{l}\text { multicenter, } \\
\text { open-label, } \\
\text { exploratory } \\
\text { study [119] }\end{array}$ & $\begin{array}{l}\text { previously stable on } \\
\text { darbepoetin Q2W i.v. or s.c. } \\
\text { with mean Hb } 10-13 \mathrm{~g} / \mathrm{dl} \text {; } \\
\mathrm{n}=58,8 \% \mathrm{Afr} . \mathrm{Am} .\end{array}$ & $\begin{array}{l}\text { extended to darbepoetin Q3W for 16-wk } \\
\text { titration }(\mathrm{n}=54) \text {; if } \mathrm{Hb} 10-13 \mathrm{~g} / \mathrm{dl} \text { during a 4- } \\
\text { week evaluation period, switched to Q4W for } \\
\text { further 16-week titration and 4-week evaluation }\end{array}$ & $\begin{array}{l}\text { of } 54 \text { patients extended to Q3W, } 38 \\
\text { qualified for switching to Q4W; } 30 \\
\text { successfully maintained } \mathrm{Hb} \\
0-13 \mathrm{~g} / \mathrm{dl} \text {, with mean final } \mathrm{Hb} 11.16 \pm \\
0.60 \mathrm{~g} / \mathrm{dl}\end{array}$ \\
\hline
\end{tabular}

Afr. Am. = African-American; BIW = twice weekly; $\mathrm{CKD}=$ chronic kidney disease; $\mathrm{Q} 1 \mathrm{~W}=$ once weekly; $\mathrm{Q} 2 \mathrm{~W}=$ every 2 weeks; $\mathrm{Q} 3 \mathrm{~W}=$ every 3 weeks; Q4W = every 4 weeks; TIW = three times weekly; U = units.

[100] revealed higher doses at increasing intervals. Of note, only 1 of 28 African-American patients achieved an extended interval (Q4W) in this study. Long-interval darbepoetin regimens have also been studied extensively in patients not requiring dialysis (table 3) [101, 102].

\section{Anemia Treatment in the Dialysis Population}

African-American patients experience more severe anemia on dialysis than Caucasian patients $[90,92,96]$. In a large incident dialysis cohort in 3 southern states [96], African-Americans had significantly lower mean
Hb than Caucasians (9.7 \pm 4.1 vs. $10.2 \pm 3.6$ g/dl; $\mathrm{p}<$ $0.0001)$. The rate of anemia treatment during dialysis varies not only regionally [103] but also by neighborhood ethnicity within cities [104]. Lack of transportation is a frequent obstacle to dialysis adherence in this population [105]; anemia management regimens relying on frequent in-center ESA and iron administration can be destabilized by the resulting missed sessions [106, 107].

African-Americans on hemodialysis are more likely than Caucasian patients to receive a suboptimal dose of dialysis [90], especially in inner-city dialysis facilities 
[104]. Adequate dialysis enhances anemia management and reduces ESA dose requirements [108]. Iron loss incurred in hemodialysis requires intravenous repletion, for which iron sucrose or iron gluconate are often used [68]. Emerging iron agents suitable for dialysis patients include infusible preparations designed to minimize free iron toxicity, as well as intradialysate ferric pyrophosphate [88].

Fewer African-American patients than Caucasian or Asian-American patients select peritoneal dialysis, a modality typically associated with lesser ESA doses and iron requirements $[109,110]$. About $80-90 \%$ of peritoneal dialysis patients require ESA therapy to maintain $\mathrm{Hb}>11$ $\mathrm{g} / \mathrm{dl}[27,111]$. In a US retrospective study, $80 \%$ of hemodialysis patients and $25 \%$ of peritoneal dialysis patients were receiving EPO 3 months after dialysis, at average doses of 60,000 and 30,000 units, respectively [110]. African-Americans comprised $25 \%$ of the hemodialysis cohort and $13 \%$ of the peritoneal cohort [110]. Peritoneal dialysis patients were less likely to receive ESA treatment and received lower doses than hemodialysis patients in this study. Nevertheless, it is difficult to distinguish whether this represented reduced ESA requirements (peritoneal dialysis causes less blood loss than hemodialysis) or less-aggressive ESA treatment strategies for peritoneal dialysis versus hemodialysis patients. Given the naturally lower baseline $\mathrm{Hb}$ levels seen in AfricanAmericans, it is not known if the concerns raised by aggressive $\mathrm{Hb}$ normalization would be intensified in this patient group.

\section{Hemoglobin Targets and Safety Considerations}

Publication in 2006 of 2 clinical trials of EPO therapy in CKD patients not on dialysis $[78,79]$ resulted in FDAmandated ESA labeling changes $[80,112,113]$ and rethinking of $\mathrm{Hb}$ targets [73]. The Cardiovascular Risk Reduction by Early Anemia Treatment with Epoetin Beta (CREATE) study [78] ( $\mathrm{n}=603$ patients with $\mathrm{Hb} 11-12.5$ $\mathrm{g} / \mathrm{dl}$ ) examined treatment with epoetin- $\beta$ to increase $\mathrm{Hb}$ to either $13.0-15.0 \mathrm{~g} / \mathrm{dl}$ or $10.5-11.5 \mathrm{~g} / \mathrm{dl}$; ethnicities were not reported. Complete correction of $\mathrm{Hb}$ levels to 13.0 $15.0 \mathrm{~g} / \mathrm{dl}$ did not increase time to first cardiovascular events in comparison with partial correction to $\mathrm{Hb}$ levels of 10.5-11.5 g/dl; frequency of or time to cardiovascular or all-cause death did not differ between groups. The CREATE results indicated that $\mathrm{Hb}$ targets exceeding 13 $\mathrm{g} / \mathrm{dl}$ did not provide additional benefit in comparison to the lower $\mathrm{Hb}$ target group [73].

In the Correction of Hemoglobin and Outcomes in Renal Insufficiency (CHOIR) trial [79], 715 patients
(28.6\% African-American) received epoetin- $\alpha$ treatment to a $\mathrm{Hb}$ target of $13.5 \mathrm{~g} / \mathrm{dl} ; 717$ patients $(29.3 \%$ AfricanAmerican) were treated to a target of $11.3 \mathrm{~g} / \mathrm{dl}$. The composite endpoint (death, myocardial infarction, hospitalization for congestive heart failure without dialysis onset, and stroke) occurred more frequently in the high- $\mathrm{Hb}$ group than the low-Hb group (125 vs. 97 events, respectively; hazard ratio, 1.34; 95\% confidence interval, $1.03-$ $1.74 ; \mathrm{p}=0.03$ ), and the trial was stopped prematurely [79]. Of note, $38 \%$ of CHOIR patients withdrew from the study early, and the distribution of prevalent hypertension and coronary artery bypass histories suggests that the groups may have begun with unequal cardiovascular risk burdens. Additionally, hyporesponse to epoetin may have increased dose-dependent adverse events in CHOIR. Patients who never attained target $\mathrm{Hb}$ received mean doses of 11,098 units/week in the low-Hb group and 12,884 units/week in the high-Hb group, whereas those attaining target $\mathrm{Hb}$ averaged 6,057 units/week (low-Hb group) and 10,694 units/week (high-Hb group).

The CREATE and CHOIR results echo an earlier study in dialysis patients [114] showing increases in blood pressure and cardiovascular events in ESRD patients with congestive heart failure or ischemic heart disease randomized to achieve normalization of $\mathrm{Hb}$. Of interest, even patients who did not achieve higher $\mathrm{Hb}$ levels in the group randomized to reach normal $\mathrm{Hb}$ levels had increased mortality, suggesting that excessive administration of ESAs and iron to hyporesponsive patients may contribute to excess mortality. The ongoing Trial to Reduce Cardiovascular Events with Aranesp (TREAT), comparing darbepoetin treatment (target $\mathrm{Hb} 13.0 \mathrm{~g} / \mathrm{dl}$ ) versus placebo in patients with diabetic nephropathy, was recently evaluated by its Data Safety and Monitoring Board in view of CHOIR and CREATE, and interim results supported its continuation [115]. Thus, the debate continues as to the potential adverse effects of achieving higher $\mathrm{Hb}$ levels in $\mathrm{CKD}$ versus the manner in which a higher $\mathrm{Hb}$ is achieved.

The ACCORD (The Anemia Correction in Diabetes) study was recently concluded and reported that there was no difference in left ventricular mass nor was there a difference in the rate of decrease in creatinine clearance in subjects randomized to a $\mathrm{Hb}$ target of 13.5 vs. 12.1 [127]. However, there was improved quality of life with the higher $\mathrm{Hb}$ target with no difference in adverse events between the two groups [127].

While the risk of elevated hemoglobin values continues to be debated, the adverse consequences of a low hemoglobin level was recently reinforced by Ishani et al. 
[132] who reported on over 50,000 dialysis patients and found a 1.7-fold relative risk of hospitalization and 2.5fold relative risk of mortality in those with more months with hemoglobin below the K/DOQI target of $11 \mathrm{~g} / \mathrm{dl}$.

Importantly, patients in ESA clinical trials receive high doses of ESAs and iron supplementation intended to achieve rapid separation of mean $\mathrm{Hb}$ between high and low target groups; this approach differs from real-world clinical practice. Even so, typically around $50 \%$ of trial participants achieve goal $\mathrm{Hb}$, and some fail to respond despite receiving high ESA doses. Further research is needed to ascertain whether adverse events result from aggressively increasing ESA doses in hyporesponsive patients without correcting the source of hyporesponse (inflammation or other comorbidities). In clinical practice, a conservative approach to ESA therapy with $\mathrm{Hb}$ goal of $11-12 \mathrm{~g} / \mathrm{dl}$ and early and stringent blood pressure control is presently recommended for all patients, irrespective of their racial origin [73].

\section{Eliminating Ethnic Disparities in Anemia and Chronic Kidney Disease: Strategies and Goals}

In summary, as discussed above, CKD is highly prevalent among African-Americans, progressing to ESRD at roughly quadruple the rate in Caucasians $[2,7]$. Early diagnosis and treatment of CKD may be lifesaving; 20-50 times as many patients die in the predialysis stages of CKD (often from cardiovascular complications) than survive to ESRD requiring dialysis or transplantation [5]. As we have seen, diabetes and hypertension, contribute to disproportionate CKD progression among AfricanAmericans, and for various reasons this patient population may respond differently to treatment regimens. Moreover, African-Americans have lower $\mathrm{Hb}$ levels at dialysis initiation and are less likely to receive ESA treatment prior to dialysis.

Once dialysis is initiated, African-Americans receive higher ESA doses [90-92]; however, it is difficult to distinguish the effects of nutritional deficiency, lower pretreatment $\mathrm{Hb}$ levels, and delayed ESA initiation from possible racial-specific biological effects on ESA responsiveness. Awareness of racial-specific challenges in anemia management in addition to CKD risk factors, progression, complications, and treatment responses will help physicians serve African-American kidney patients more effectively. Racial $\mathrm{Hb}$ variations superimposed on the effects of CKD warrant further review and possibly racial-specific guidelines for anemia diagnosis and treatment [12].
Crucial interventions to reduce CKD progression and cardiovascular disease include lifestyle modification and the treatment of hypertension, diabetes, dyslipidemia, as well as anemia [1]. Physicians need to advocate for improved healthcare access in minority communities and counsel patients on nutrition, exercise, and prevention of obesity and substance abuse [105]. Early identification of $\mathrm{CKD}$ and anemia in African-Americans is paramount in order to prevent progression of CKD and cardiovascular disease.

Clinical outcomes, comorbidities, disease progression, and health-related behavior and attitudes in minority populations require further study [90]. Ethnic minorities are currently underrepresented in clinical trials, contributing to lacunae in evidence-based recommendations [1]; ethnically diverse trials are necessary to understand possible differences in response to pharmacotherapy for CKD-related conditions such as anemia [94]. Increased understanding of the patterns and causes of racial disparities in CKD will allow for a more tailored management strategy for different racial and ethnic groups [105]. Proactive management of CKD and its complications, including anemia, throughout its course can alleviate the impact of ESRD on African-Americans at a public health level.

\section{Acknowledgments}

Dr. Keith Norris has received research support from NIH grants RR011145, RR014616, RR019234, and MD000182.

The authors acknowledge the editorial assistance of Kim Coleman Healy, $\mathrm{PhD}$ from Envision Pharma (supported with funds from Roche) in the development of the manuscript. The funding source did not review or comment upon the manuscript or provide any remuneration to the authors.

References

1 Lakkis J, Weir MR: Pharmacological strategies for kidney function preservation: are there differences by ethnicity? Adv Ren Replace Ther 2004;11:24-40.

2 United States Renal Data System: USRDS Annual Data Report: Atlas of End-Stage Renal Disease in the United States. Bethesda, National Institutes of Health, National Institute of Diabetes and Digestive and Kidney Disorders, 2006.

-3 Jamerson KA: Preventing chronic kidney disease in special populations. Am J Hypertens 2005; 18:106S-111S.

4 Prevalence of chronic kidney disease and associated risk factors: United States, 1999 2004. MMWR Morb Mortal Wkly Rep 2007; 56:161-165. 
-5 National Kidney Foundation-Kidney Early Evaluation Program: KEEP annual data report 2006. Am J Kidney Dis 2007;49:S1S160.

-6 Hsu CY, Lin F, Vittinghoff E, Shlipak MG: Racial differences in the progression from chronic renal insufficiency to end-stage renal disease in the United States. J Am Soc Nephrol 2003;14:2902-2907.

7 Tareen N, Zadshir A, Martins D, Pan D, Nicholas S, Norris K: Chronic kidney disease in African American and Mexican American populations. Kidney Int 2005;97(suppl): S137-S140.

$>8$ El-Achkar TM, Ohmit SE, McCullough PA, Crook ED, Brown WW, Grimm R, Bakris GL, Keane WF, Flack JM: Higher prevalence of anemia with diabetes mellitus in moderate kidney insufficiency: The Kidney Early Evaluation Program. Kidney Int 2005;67: 1483-1488.

-9 Astor BC, Arnett DK, Brown A, Coresh J: Association of kidney function and hemoglobin with left ventricular morphology among African Americans: the Atherosclerosis Risk in Communities (ARIC) study. Am J Kidney Dis 2004; 43:836-845.

10 Silverberg D: Outcomes of anaemia management in renal insufficiency and cardiac disease. Nephrol Dial Transplant 2003;18(suppl 2):ii7-ii12.

-11 Lefebvre P, Duh MS, Mody SH, Bookhart B, Piech CT: The economic impact of epoetin alfa therapy on delaying time to dialysis in elderly patients with chronic kidney disease. Dis Manag 2007;10:37-45.

$\checkmark 12$ Beutler E, West C: Hematologic differences between African-Americans and whites: the roles of iron deficiency and alpha-thalassemia on hemoglobin levels and mean corpuscular volume. Blood 2005;106:740-745.

$\checkmark 13$ Killip S, Bennett JM, Chambers MD: Iron deficiency anemia. Am Fam Physician 2007; 75:671-678.

14 Berns JS: Should all patients with chronic kidney disease receive an EPO-type drug? Cleve Clin J Med 2006;73:298-300.

-15 Foley RN, Parfrey PS, Harnett JD, Kent GM, Murray DC, Barre PE: The impact of anemia on cardiomyopathy, morbidity, and mortality in end-stage renal disease. Am J Kidney Dis 1996;28:53-61.

-16 Levin A, Thompson CR, Ethier J, Carlisle EJ, Tobe S, Mendelssohn D, Burgess E, Jindal K, Barrett B, Singer J, Djurdjev O: Left ventricular mass index increase in early renal disease: impact of decline in hemoglobin. Am J Kidney Dis 1999;34:125-134.

- 17 Walker AM, Schneider G, Yeaw J, Nordstrom B, Robbins S, Pettitt D: Anemia as a predictor of cardiovascular events in patients with elevated serum creatinine. J Am Soc Nephrol 2006;17:2293-2298.

-18 Khan SS, Kazmi WH, Abichandani R, Tighiouart H, Pereira BJ, Kausz AT: Health care utilization among patients with chronic kidney disease. Kidney Int 2002;62:229-236.
19 Powe NR, Griffiths RI, Watson AJ, Anderson GF, de Lissovoy G, Greer JW, Herbert RJ, Milam RA, Whelton PK: Effect of recombinant erythropoietin on hospital admissions, readmissions, length of stay, and costs of dialysis patients. J Am Soc Nephrol 1994;4:14551465.

20 Collins AJ: Anaemia management prior to dialysis: cardiovascular and cost-benefit observations. Nephrol Dial Transplant 2003; 18(suppl 2):ii2-ii6.

21 Hayashi T, Suzuki A, Shoji T, Togawa M, Okada N, Tsubakihara Y, Imai E, Hori M: Cardiovascular effect of normalizing the hematocrit level during erythropoietin therapy in predialysis patients with chronic renal failure. Am J Kidney Dis 2000;35:250-256.

22 Lu WX, Jones-Burton C, Zhan M, Salzberg DJ, Moore J Jr, Fink JC: Survival benefit of recombinant human erythropoietin administration prior to onset of end-stage renal disease: variations across surrogates for quality of care and time. Nephron Clin Pract 2005;101:c79-c86.

23 Kovesdy CP, Trivedi BK, Kalantar-Zadeh K, Anderson JE: Association of anemia with outcomes in men with moderate and severe chronic kidney disease. Kidney Int 2006;69: 560-564.

24 Besarab A, Frinak S, Yee J: An indistinct balance: the safety and efficacy of parenteral iron therapy. J Am Soc Nephrol 1999;10: 2029-2043.

25 Ward HJ: Implications of recombinant erythropoietin therapy for renal transplantation. Am J Nephrol 1990;10(suppl 2):4447; discussion 48-52.

26 Sexauer CL, Matson JR: Anemia of chronic renal failure. Ann Clin Lab Sci 1981;11:484487.

27 National Kidney Foundation: KDOQI clinical practice guidelines and clinical practice recommendations for anemia in chronic kidney disease. Am J Kidney Dis 2006;47: S11-S145.

28 Eschbach JW, Egrie JC, Downing MR, Browne JK, Adamson JW: Correction of the anemia of end-stage renal disease with recombinant human erythropoietin: results of a combined phase I and II clinical trial. N Engl J Med 1987;316:73-78.

29 Egrie JC, Browne JK: Development and characterization of novel erythropoiesis stimulating protein (NESP). Nephrol Dial Transplant 2001;16(suppl 3):3-13.

30 Macdougall IC, Eckardt KU: Novel strategies for stimulating erythropoiesis and potential new treatments for anaemia. Lancet 2006;368:947-953.

31 Salem M: End-stage renal disease survival in blacks and whites. Am J Med Sci 2002;323: 100-101.

-32 Norris KC, Agodoa LY: Unraveling the racial disparities associated with kidney disease. Kidney Int 2005;68:914-924.
3 Powe NR: To have and have not: health and health care disparities in chronic kidney disease. Kidney Int 2003;64:763-772.

34 Freedman BI: End-stage renal failure in African Americans: insights in kidney disease susceptibility. Nephrol Dial Transplant 2002;17:198-200.

35 Adler S: Renal disease: environment, race, or genes? Ethn Dis 2006;16(suppl 2):35-39.

36 Peralta CA, Ziv E, Katz R, Reiner A, Burchard EG, Fried L, Kwok PY, Psaty B, Shlipak $\mathrm{M}$ : African ancestry, socioeconomic status, and kidney function in elderly African Americans: a genetic admixture analysis. J Am Soc Nephrol 2006; 17:3491-3496.

37 Boone CA: End-stage renal disease in African-Americans. Nephrol Nurs J 2000;27: 597-600.

38 Price DA, Owen WF Jr: African-Americans on maintenance dialysis: a review of racial differences in incidence, treatment, and survival. Adv Ren Replace Ther 1997;4:3-12.

39 Young CJ, Kew C: Health disparities in transplantation: focus on the complexity and challenge of renal transplantation in African Americans. Med Clin North Am 2005;89: 1003-1031.

40 Douglas JG, Bakris GL, Epstein M, Ferdinand KC, Ferrario C, Flack JM, Jamerson KA, Jones WE, Haywood J, Maxey R, Ofili EO, Saunders E, Schiffrin EL, Sica DA, Sowers JR, Vidt DG: Management of high blood pressure in African Americans: consensus statement of the hypertension in African Americans working group of the International Society on Hypertension in Blacks. Arch Intern Med 2003; 163:525-541.

41 Lea J, Greene T, Hebert L, Lipkowitz M, Massry S, Middleton J, Rostand SG, Miller E, Smith W, Bakris GL: The relationship between magnitude of proteinuria reduction and risk of end-stage renal disease: results of the African American study of kidney disease and hypertension. Arch Intern Med 2005;165:947-953.

42 Toto RD: Proteinuria and hypertensive nephrosclerosis in African Americans. Kidney Int 2004;92(suppl):S102-S104.

43 Toto RD: Lessons from the African-American study of kidney disease and hypertension: an update. Curr Hypertens Rep 2006;8: 409-412.

44 Martins D, Tareen N, Zadshir A, Pan D, Vargas R, Nissenson A, Norris K: The association of poverty with the prevalence of albuminuria: data from the Third National Health and Nutrition Examination Survey (NHANES III). Am J Kidney Dis 2006;47: 965-971.

45 Schreuder MF, Nauta J: Prenatal programming of nephron number and blood pressure. Kidney Int 2007;72:265-268.

46 Grella PV: Low birth weight and early life origins of adult disease: insulin resistance and type 2 diabetes. Clin Exp Obstet Gynecol 2007;34:9-13. 
-47 Haas M: Hypertension, race, and glomeruli: more than simply a numbers game. Kidney Int 2006;69:640-642.

48 Hughson MD, Douglas-Denton R, Bertram JF, Hoy WE: Hypertension, glomerular number, and birth weight in African Americans and white subjects in the southeastern United States. Kidney Int 2006;69:671-678.

49 Neal L, Greene EL: Pathophysiology of chronic progressive renal disease in the African American patient with hypertension. Am J Med Sci 2002;323:72-77.

-50 Weir MR, Chrysant SG, McCarron DA, Canossa-Terris M, Cohen JD, Gunter PA, Lewin AJ, Mennella RF, Kirkegaard LW, Hamilton $\mathrm{JH}$, Weinberger $\mathrm{MH}$, Weder AB: Influence of race and dietary salt on the antihypertensive efficacy of an angiotensinconverting enzyme inhibitor or a calcium channel antagonist in salt-sensitive hypertensives. Hypertension 1998;31:1088-1096.

51 Hall JE: Mechanisms of abnormal renal sodium handling in obesity hypertension. Am J Hypertens 1997;10:49S-55S.

-52 Walker WG, Neaton JD, Cutler JA, Neuwirth $\mathrm{R}$, Cohen JD: Renal function change in hypertensive members of the Multiple Risk Factor Intervention Trial: racial and treatment effects. The MRFIT research group. JAMA 1992;268:3085-3091.

- 53 Lewis J, Greene T, Appel L, Contreras G, Douglas J, Lash J, Toto R, Van Lente F, Wang X, Wright JT Jr: A comparison of iothalamate-GFR and serum creatinine-based outcomes: acceleration in the rate of GFR decline in the African American study of kidney disease and hypertension. J Am Soc Nephrol 2004;15:3175-3183.

54 Appel LJ, Middleton J, Miller ER, 3rd, Lipkowitz M, Norris K, Agodoa LY, Bakris G, Douglas JG, Charleston J, Gassman J, Greene T, Jamerson K, Kusek JW, Lewis JA, Phillips RA, Rostand SG, Wright JT: The rationale and design of the AASK cohort study. J Am Soc Nephrol 2003;14:S166-S172.

55 Kaperonis N, Bakris G: Blood pressure, antihypertensive therapy and risk for renal injury in African-Americans. Curr Opin Nephrol Hypertens 2003;12:79-84.

56 Wright JT Jr, Dunn JK, Cutler JA, Davis BR, Cushman WC, Ford CE, Haywood LJ, Leenen FH, Margolis KL, Papademetriou V, Probstfield JL, Whelton PK, Habib GB: Outcomes in hypertensive black and nonblack patients treated with chlorthalidone, amlodipine, and lisinopril. JAMA 2005;293:15951608.

57 Ferdinand KC: Recommendations for the management of special populations: Racial and ethnic populations. Am J Hypertens 2003; 16:50S-54S

58 Douglas JG, Agodoa L: ACE inhibition is effective and renoprotective in hypertensive nephrosclerosis: The African American study of kidney disease and hypertension (aask) trial. Kidney Int 2003;91(suppl):S74S76.
59 Agodoa LY, Appel L, Bakris GL, et al: Effect of ramipril vs amlodipine on renal outcomes in hypertensive nephrosclerosis: a randomized controlled trial. JAMA 2001;285:27192728.

60 Norris KC, Greene T, Kopple J, Lea J, Lewis J, Lipkowitz M, Miller P, Richardson A, Rostand S, Wang X, Appel LJ: Baseline predictors of renal disease progression in the African American study of hypertension and kidney disease. J Am Soc Nephrol 2006;17: 2928-2936.

61 Harris MI, Flegal KM, Cowie CC, Eberhardt MS, Goldstein DE, Little RR, Wiedmeyer HM, Byrd-Holt DD: Prevalence of diabetes, impaired fasting glucose, and impaired glucose tolerance in US adults: the Third National Health and Nutrition Examination Survey, 1988-1994. Diabetes Care 1998;21: 518-524.

62 Martins D, Tareen N, Norris KC: The epidemiology of end-stage renal disease among African Americans. Am J Med Sci 2002;323: 65-71.

63 Crook ED: Diabetic renal disease in African Americans. Am J Med Sci 2002;323:78-84.

64 Martins D, Norris K: Combating diabetic nephropathy with drug therapy. Curr Diab Rep 2001;1:148-156.

65 McClellan W, Aronoff SL, Bolton WK, Hood S, Lorber DL, Tang KL, Tse TF, Wasserman B, Leiserowitz M: The prevalence of anemia in patients with chronic kidney disease. Curr Med Res Opin 2004;20:1501-1510.

66 Thomas MC, Tsalamandris C, MacIsaac RJ, Jerums G: The epidemiology of hemoglobin levels in patients with type 2 diabetes. Am J Kidney Dis 2006;48:537-545.

67 McCullough PA, Lepor NE: The deadly triangle of anemia, renal insufficiency, and cardiovascular disease: implications for prognosis and treatment. Rev Cardiovasc Med 2005;6:1-10.

68 Nurko S: Anemia in chronic kidney disease: causes, diagnosis, treatment. Cleve Clin J Med 2006;73:289-297.

69 Foley RN, Parfrey PS, Harnett JD, Kent GM, Martin CJ, Murray DC, Barre PE: Clinical and echocardiographic disease in patients starting end-stage renal disease therapy. Kidney Int 1995;47:186-192.

70 East MA, Jollis JG, Nelson CL, Marks D, Peterson ED: The influence of left ventricular hypertrophy on survival in patients with coronary artery disease: do race and gender matter? J Am Coll Cardiol 2003;41:949954.

71 Ayus JC, Go AS, Valderrabano F, Verde E, de Vinuesa SG, Achinger SG, Lorenzo V, Arieff AI, Luno J: Effects of erythropoietin on left ventricular hypertrophy in adults with severe chronic renal failure and hemoglobin $<10$ g/dl. Kidney Int 2005;68:788-795.
72 Cody J, Daly C, Campbell M, Donaldson C, Khan I, Rabindranath K, Vale L, Wallace S, Macleod A: Recombinant human erythropoietin for chronic renal failure anaemia in pre-dialysis patients. Cochrane Database Syst Rev 2005:CD003266.

73 KDOQI Clinical Practice Guideline and Clinical Practice Recommendations for Anemia in Chronic Kidney Disease: 2007 update of hemoglobin target. Am J Kidney Dis 2007;50:471-530.

74 Dean BB, Dylan M, Gano A Jr, Knight K, Ofman JJ, Levine BS: Erythropoiesis-stimulating protein therapy and the decline of renal function: a retrospective analysis of patients with chronic kidney disease. Curr Med Res Opin 2005;21:981-987.

75 Jungers P, Choukroun G, Oualim Z, Robino C, Nguyen AT, Man NK: Beneficial influence of recombinant human erythropoietin therapy on the rate of progression of chronic renal failure in predialysis patients. Nephrol Dial Transplant 2001;16:307-312.

76 Gouva C, Nikolopoulos P, Ioannidis JP, Siamopoulos KC: Treating anemia early in renal failure patients slows the decline of renal function: a randomized controlled trial. Kidney Int 2004;66:753-760.

77 Fink J, Blahut S, Reddy M, Light P: Use of erythropoietin before the initiation of dialysis and its impact on mortality. Am J Kidney Dis 2001;37:348-355.

78 Drueke TB, Locatelli F, Clyne N, Eckardt KU, Macdougall IC, Tsakiris D, Burger HU, Scherhag A: Normalization of hemoglobin level in patients with chronic kidney disease and anemia. N Engl J Med 2006;355:2071-2084.

79 Singh AK, Szczech L, Tang KL, Barnhart H, Sapp S, Wolfson M, Reddan D: Correction of anemia with epoetin alfa in chronic kidney disease. N Engl J Med 2006;355:2085-2098.

80 Food and Drug Administration: Information for healthcare professionals: Erythropoiesis stimulating agents (ESA) [Aranesp (darbepoetin), Epogen (epoetin alfa), and Procrit (epoetin alfa), 2007. http://www.fda.gov/cder/ drug/InfoSheets/HCP/RHE2007HCP.htm.

81 Deicher R, Horl WH: Differentiating factors between erythropoiesis-stimulating agents: a guide to selection for anaemia of chronic kidney disease. Drugs 2004;64:499-509.

82 Macdougall IC, Robson R, Opatrna S, Liogier X, Pannier A, Jordan P, Dougherty FC, Reigner B: Pharmacokinetics and pharmacodynamics of intravenous and subcutaneous continuous erythropoietin receptor activator (CERA) in patients with chronic kidney disease. Clin J Am Soc Nephrol 2006;1:12111215.

83 Sulowicz W, Locatelli F, Ryckelynck JP, Balla J, Csiky B, Harris K, Ehrhard P, Beyer U: Once-monthly subcutaneous CERA maintains stable hemoglobin control in patients with chronic kidney disease on dialysis and converted directly from epoetin one to three times weekly. Clin J Am Soc Nephrol 2007;2: 637-646. 
84 de Francisco AL, Sulowicz W, Klinger M, Niemczyk S, Vargemezis V, Metivier F, Dougherty FC, Oguey D: Continuous erythropoietin receptor activator (CERA) administered at extended administration intervals corrects anaemia in patients with chronic kidney disease on dialysis: a randomised, multicentre, multiple-dose, phase II study. Int J Clin Pract 2006;60:1687-1696.

-85 Provenzano R, Besarab A, Macdougall IC, Ellison DH, Maxwell AP, Sulowicz W, Klinger M, Rutkowski B, Correa-Rotter R, Dougherty FC: The continuous erythropoietin receptor activator (CERA) corrects anemia at extended administration intervals in patients with chronic kidney disease not on dialysis: results of a phase II study. Clin Nephrol 2007;67:306-317.

-86 Fan Q, Leuther KK, Holmes CP, Fong KL, Zhang J, Velkovska S, Chen MJ, Mortensen RB, Leu K, Green JM, Schatz PJ, Woodburn KW: Preclinical evaluation of hematide, a novel erythropoiesis stimulating agent, for the treatment of anemia. Exp Hematol 2006; 34:1303-1311.

87 Stead RB, Lambert J, Wessels D, Iwashita JS, Leuther KK, Woodburn KW, Schatz PJ, Okamoto DM, Naso R, Duliege AM: Evaluation of the safety and pharmacodynamics of hematide, a novel erythropoietic agent, in a phase 1, double-blind, placebo-controlled, dose-escalation study in healthy volunteers. Blood 2006;108:1830-1834.

-88 Rastogi A, Nissenson AR: New approaches to the management of anemia of chronic kidney disease: beyond Epogen and Infed. Kidney Int 2006;70(suppl):S14-S16.

89 Haase VH: Hypoxia-inducible factors in the kidney. Am J Physiol 2006;291:F271-F281.

90 Gadegbeku C, Freeman M, Agodoa L: Racial disparities in renal replacement therapy. J Natl Med Assoc 2002;94:45S-54S.

-91 Coladonato JA, Frankenfield DL, Reddan DN, Klassen PS, Szczech LA, Johnson CA, Owen WF Jr: Trends in anemia management among US hemodialysis patients. J Am Soc Nephrol 2002;13:1288-1295.

-92 Frankenfield DL, Rocco MV, Frederick PR, Pugh J, McClellan WM, Owen WF Jr: Racial/ ethnic analysis of selected intermediate outcomes for hemodialysis patients: results from the 1997 ESRD core indicators project. Am J Kidney Dis 1999;34:721-730.

-93 Ifudu O: Patient characteristics determining rHuEPO dose requirements. Nephrol Dial Transplant 2002;17(suppl 5):38-41.

94 Jones-Burton C, Seliger SL, Brown J, Stackiewicz L, Hsu VD, Fink JC: Racial variations in erythropoietic response to epoetin alfa in chronic kidney disease and the impact of smoking. Nephrol Dial Transplant 2005;20: 2739-2745.

-95 Obrador GT, Roberts T, St Peter WL, Frazier E, Pereira BJ, Collins AJ: Trends in anemia at initiation of dialysis in the United States. Kidney Int 2001;60:1875-1884.
$\$ 96$ Volkova N, McClellan W, Soucie JM, Schoolwerth A: Racial disparities in the prevalence of cardiovascular disease among incident end-stage renal disease patients. Nephrol Dial Transplant 2006;21: 2202-2209.

97 Besarab A: Resolving the paradigm crisis in intravenous iron and erythropoietin management. Kidney Int 2006;70(suppl): S13-S18.

98 Heme Iron Polypeptide: A radically different oral iron. Nephrol News Issues 2002;16: 39-41.

99 Provenzano R, Bhaduri S, Singh AK: Extended epoetin alfa dosing as maintenance treatment for the anemia of chronic kidney disease: the PROMPT study. Clin Nephrol 2005;64:113-123.

100 Germain M, Ram CV, Bhaduri S, Tang KL, Klausner M, Curzi M: Extended epoetin alfa dosing in chronic kidney disease patients: a retrospective review. Nephrol Dial Transplant 2005;20:2146-2152.

101 Ling B, Walczyk M, Agarwal A, Carroll W, Liu W, Brenner R: Darbepoetin alfa administered once monthly maintains hemoglobin concentrations in patients with chronic kidney disease. Clin Nephrol 2005;63:327334.

102 Hertel J, Locay H, Scarlata D, Jackson L, Prathikanti R, Audhya P: Darbepoetin alfa administered every other week maintains hemoglobin levels over 52 weeks in patients with chronic kidney disease converting from once-weekly recombinant human erythropoietin: results from Simplify the Treatment of Anemia with Aranesp (STAAR). Am J Nephrol 2006;26:149-156.

103 Reddan DN, Frankenfield DL, Klassen PS, Coladonato JA, Szczech L, Johnson CA, Besarab A, Rocco M, McClellan W, Wish J, Owen WF Jr: Regional variability in anaemia management and haemoglobin in the US. Nephrol Dial Transplant 2003;18:147152.

104 Rodriguez RA, Sen S, Mehta K, MoodyAyers S, Bacchetti P, O'Hare AM: Geography matters: relationships among urban residential segregation, dialysis facilities, and patient outcomes. Ann Intern Med 2007;146:493-501.

105 Nzerue CM, Demissochew H, Tucker JK: Race and kidney disease: Role of social and environmental factors. J Natl Med Assoc 2002;94:28S-38S.

106 Ifudu O, Chan E, Paul H, Mayers JD, Cohen LS, Brezsnyak WF, Herman AI, Avram MM, Friedman EA: Anemia severity and missed dialysis treatments in erythropoietin-treated hemodialysis patients. ASAIO J 1996;42:146-149.
107 Foley RN, Li Q, Gilbertson DT, Collins AJ, Dunning SC: Association between missed dialysis sessions and hemoglobin variability in the US. Poster F-PO375, presented November 17, 2006. San Diego, American Society of Nephrology Annual Meeting, 2006.

108 Locatelli F, Del Vecchio L, Pozzoni P, Andrulli S: Dialysis adequacy and response to erythropoiesis-stimulating agents: what is the evidence base? Semin Nephrol 2006;26: 269-274.

109 Horl WH: Anemia and its treatment in peritoneal dialysis patients. Wien Klin Wochenschr 2005;117(suppl 6):69-72.

110 Snyder JJ, Foley RN, Gilbertson DT, Vonesh EF, Collins AJ: Hemoglobin levels and erythropoietin doses in hemodialysis and peritoneal dialysis patients in the United States. J Am Soc Nephrol 2004;15:174-179.

111 Macdougall IC: How to optimise anaemia therapy in peritoneal dialysis patients. Contrib Nephrol. Basel, Karger, 2006, vol 150, pp 202-213.

112 Epogen $^{\circledR}$ (US prescribing information). Thousand Oaks, Amgen, Inc., 2007.

113 Aranesp $^{\circledR}$ (US prescribing information). Thousand Oaks, Amgen, Inc., 2007.

114 Besarab A, Bolton WK, Browne JK, Egrie JC, Nissenson AR, Okamoto DM, Schwab SJ, Goodkin DA: The effects of normal as compared with low hematocrit values in patients with cardiac disease who are receiving hemodialysis and epoetin. N Engl J Med 1998;339:584-590.

115 Pfeffer MA: An ongoing study of anemia correction in chronic kidney disease. $\mathrm{N}$ Engl J Med 2007;356:959-961.

116 Hostetter TH: Research opportunities for reducing racial disparities in kidney disease. Adv Ren Replace Ther 2004;11:5965.

117 National Kidney Foundation: K/DOQI clinical practice guidelines for chronic kidney disease: evaluation, classification, and stratification. Am J Kidney Dis 2002;39: S1-S266.

118 Cody J, Daly C, Campbell M, Donaldson C, Khan I, Vale L, Wallace S, Macleod A: Frequency of administration of recombinant human erythropoietin for anaemia of endstage renal disease in dialysis patients. Cochrane Database Syst Rev 2005:CD003895.

119 Jadoul M, Vanrenterghem Y, Foret M, Walker R, Gray SJ: Darbepoetin alfa administered once monthly maintains haemoglobin levels in stable dialysis patients. Nephrol Dial Transplant 2004;19:898-903.

120 Macdougall IC, Walker R, Provenzano R; ARCTOS Study Investigators: C.E.R.A. (continuous erythropoietin receptor activator) administered at extended intervals corrects anemia and maintains stable $\mathrm{Hb}$ levels in patients with CKD not on dialysis. Poster Sa-PO208, presented November 18, 2006. San Diego, American Society of Nephrology 39th Annual Meeting, 2006. 
121 Klinger M, Arias M, Vargemezis V; AMICUS Study Investigators: C.E.R.A. (continuous erythropoietin receptor activator) administered at extended intervals corrects $\mathrm{Hb}$ levels in patients with CKD on dialysis. Poster Sa-PO212, presented November 18, 2006. San Diego, American Society of Nephrology 39th Annual Meeting, 2006.

122 Fishbane S, Levin NW, Mann JFE, MAXIMA Study Investigators: IV CERA (continuous erythropoietin receptor activator) once every 2 weeks or once monthly maintains stable $\mathrm{Hb}$ levels after converting directly from IV epoetin 1-3 times per week in patients with CKD on dialysis. Poster SaPO205, presented November 18, 2006. San Diego, American Society of Nephrology 39th Annual Meeting, 2006.

123 Canaud B, Braun J, Locatelli F; STRIATA Study Investigators: C.E.R.A. (continuous erythropoietin receptor activator) administered once every 2 weeks maintains stable hemoglobin $(\mathrm{Hb})$ levels in patients with chronic kidney disease on dialysis. 43rd European Renal Association-European Dialysis and Transplant Association Congress, Glasgow, 2006.
124 O’Mara NB, Kapoian T: Continuous erythropoiesis receptor activator (CERA): an erythropoiesis-stimulating agent for the treatment of anemia in patients with chronic kidney disease. Formulary 2007;42:233244.

125 United Kingdom Prospective Diabetes Study Group: Tight blood pressure control and risk of macrovascular and microvascular complications in type 2 diabetes: UKPDS 38. Br Med J 1998;317:703-713.

126 HOT Study Group: Effects of intensive blood-pressure lowering and low-dose aspirin in patients with hypertension: principal results of the Hypertension Optimal Treatment (HOT) randomised trial. Lancet 1998;351:1755-1762.

127 Ritz E, Laville M, Bilous RW, O’Donoghue D, Scherhag A, Burger U, de Alvaro F: Target level for hemoglobin correction in patients with diabetes and CKD: primary results of the Anemia Correction in Diabetes (ACORD) Study. Am J Kidney Dis 2007;49: 194-207.
128 Perry GS, Byers T, Yip R, Margen S: Iron nutrition does not account for the hemoglobin differences between blacks and whites. J Nutr 1993;122:1417-1424.

129 McLaren CE, Li K, Gordeuk VR, Hasselblad V, McLaren GD: Relationship between transferrin saturation and iron stores in the African American and US Caucasian populations: analysis of data from the third $\mathrm{Na}$ tional Health and Nutrition Examination Survey. Blood 2001;98:2345-2351.

130 Schechter GP: Hemoglobin levels in African-Americans. Blood 2006;107:22082209.

131 Weisbord SD, Fried LF, Mor MK, Resnick AL, Kimmel PL, Palevsky PM, Fine MJ: Associations of race and ethnicity with anemia management among patients initiating renal replacement therapy. J Natl Med Assoc 2007;99:1218-1226.

132 Ishani A, Solid CA, Weinhandl ED, Gilbertson DT, Foley RN, Collins AJ: Association between number of months below K/ DOQI haemoglobin target and risk of hospitalization and death. Nephrol Dial Transplant. 2007; Epub ahead of print. 